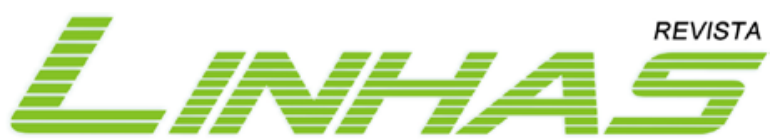

\title{
OSTRAS E JABUTICABAS
}

\section{ALVES, Rubem. Ostra feliz não faz pérola. São Paulo: Planeta, 2008, 278 p.}

ALVES, Rubem. Do universo à jabuticaba. São Paulo: Planeta, 2010, 256 p.

\author{
Vicentônio Regis do Nascimento Silva* \\ Adriana Jesuíno Francisco ${ }^{* *}$
}

Diferentemente de significativa parcela dos estudiosos - para quem a crônica instalase na transitoriedade diária do contexto político, social, econômico, cultural ou religioso Afrânio Coutinho demonstra que a efemeridade é uma de suas possibilidades, mas não a única delas. O Crítico Literário assegura a diversidade das espécies, entre as quais a crônica metafísica, “(...) constituída de reflexões mais ou menos filosóficas sobre os acontecimentos ou os homens” (COUTINHO, 2008, p. 107).

Desde meados da década passada, Rubem Alves concentra-se na libertação das notas de seus caderninhos. Observador perspicaz das mudanças líquidas das relações afetivas, seguindo a máxima de se dizer muito no essencial, alçou a crônica a transporte acessível e acessado de investidas simples contra convicções complexas, separando os escritos em grupos temáticos dos quais se origina Ostra feliz não faz pérola (segundo lugar do prêmio Jabuti) e

\section{Do universo à jabuticaba.}

As características da classificação elaborada por Afrânio Coutinho são perceptíveis: ambos os títulos empenham-se em “(...) estabelecer com o leitor uma intimidade afetuosa que o leva a se identificar à matéria exposta” (CANDIDO, 2007, p. 110-111), buscando a magnitude “(...) a ponto de se tornar exemplar ou inalcançável. E, portanto, se eternizar” (GALVANI, 2009, p. 18). A transmissão de mensagens e o desencadeamento de efeitos são

\footnotetext{
* Mestre em História pela Universidade Estadual Paulista Júlio de Mesquita Filho. E-mail: vicrenos@yahoo.com.br

** Graduanda em Letras pela Universidade Estadual Paulista Júlio de Mesquita Filho. E-mail: drimouse@yahoo.com.br
} 
suas prioridades. Personagens, lugares ou situações são secundários. Desenha-se a universalidade pela Verdade, por sua vez, erigida pela argumentação.

Durante discurso de Luis Fernando Veríssimo, uma voz da platéia indaga a fonte das inspirações nos assuntos sexuais. Resposta: "Eu tiro a minha inspiração é da saudade...” (ALVES, 2010, p. 60) Os espectadores explodem em gargalhadas. Rubem Alves condói-se do colega de ofício: sua justificativa de saudade não floresce do campo da alegria, mas dos labirintos mnemônicos de "um velho".

O exemplo assinala a crônica metafísica: irrelevantes os personagens (reais ou fictícios) ou os lugares. São importantes as mensagens e os efeitos causados no leitor. Moacyr Scliar, Eduardo Galeano ou Mario Vargas Llosa poderiam substituir Luis Fernando Veríssimo: a mensagem destina-se ao homem universal (letrado ou ignorante, crente ou ateu, liberal ou conservador) angustiado entre as saudades da juventude, a perda da segurança da idade adulta e a entrada no declínio biológico (mudanças físicas, intelectuais, psicológicas e sexuais).

Sobressaem as mensagens e o desejo de efeitos práticos, os assuntos relacionados aos temas permanentes (e, se permanentes, literários, educacionais e filosóficos), o desmantelamento da culpa e a instigação à vida. Em Ostra feliz não faz pérola, são exemplos as inquietações na edificação de caminhos que minimizem os sofrimentos, simbolizadas no incômodo causado pelo grão de areia na produção da pérola (Ostra feliz não faz pérola, p. 11-12); a superação das diferenças na composição plural da identidade coletiva, promovida pela estética e pela Arte (O pianista, p.34-35); o esclarecimento de temas cotidianos, distinguindo conceitos que se complementam e, ao mesmo tempo, são independentes como amor e casamento (Amantes, p. 78); a aplicação da inteligência docente na pesquisa de métodos que conquistem, mas que não obriguem os alunos a aprender (Desejos, p. 117-118); as dúvidas na construção do conhecimento (Dúvidas, p. 209-210).

Do universo à jabuticaba são lições pragmáticas que ensinam a, dialogando com Guimarães Rosa, compreender os sofrimentos de uma criança (Ver, p. 42-43); redimensionar os conceitos dominantes, como os que inserem os mais experientes na melhor idade, termo que, na prática, é “(....) uma mentira delicada para não humilhar os velhos” (Melhor idade?, p. 55-56); desmontar as respostas teológicas (Conversa teológica entre pai e filho, p. 120-122) ou desmascarar os discursos que tornam sinônimas a felicidade e a religião (Religião $e$ felicidade, p. 125-126); libertar-se de estigmas de comportamento (Filosofia do gato, p. 7981); utilizar satisfatoriamente o conhecimento, considerando que “a memória é um escorredor de macarrão: o que não vai ser comido, ela esquece” (Memória, p. 235-237); buscar sabedoria 
na percepção dos detalhes (Cegueira, p. 50-51) ou promover a igualdade por meio da aceitação das diferenças (O gato que gostava de cenouras, p. 215-217).

Embora as regras de técnicas literárias advirtam sobre as repetições, Rubem Alves recorre a elas como mecanismo de coesão textual. São artifícios pedagógicos de fixação de conceitos. O leitor passa despercebido sobre o primeiro alerta, recorda-se na segunda ocasião, assimila ou repudia a terceira aparição e, na quarta vez, repete o comando antes de concluir a leitura da paráfrase que

(...) acontece sempre que recorremos ao procedimento de voltar a dizer o que já foi dito antes, porém, com outras palavras, como se quiséssemos traduzir o enunciado, ou explicá-lo melhor, para deixar o conteúdo mais transparente, sem perder, no entanto, sua originalidade conceitual. A paráfrase é, portanto, uma operação de reformulação, de dizer o mesmo de outro jeito. É um recurso bastante comum nos textos explicativos, ou naqueles com função didática, nos quais há, obviamente, um interesse particular na compreensão dos pontos abordados. (ANTUNES, 2010, p. 62).

Com a finalidade de exemplificar as paráfrases pedagógicas, recorremos a Do universo à jabuticaba. A crítica ao eufemismo melhor idade - e, consequentemente, às cortinas que escondem as mazelas dos palcos - aparece em Melhor idade? (p. 55-56), Maldições da velhice (p. 61) ou Asas nos pés (p.62). Os problemas da cegueira psicológica são constatados em Cegueira (p.50-51) ou Paraíso (p.81). As argúcias das interpretações teológicas salientam-se em Jardim das delícias (p.123-124) e Meretrizes (p.133-134).

Ostra feliz não faz pérola e Do universo à jabuticaba tratam literariamente de temas filosóficos e educacionais, mas não criam sistemas filosóficos ou teorias pedagógicas: adensam-se na transmissão e na construção do conhecimento assim como na aplicação da inteligência. Se, por um lado, as mensagens são eficazmente transmitidas, por outro, apenas estudos mais profundos avaliariam seus efeitos à medida que os leitores saem das crônicas conscientes sobre o que fazer, mas não habilitados sobre como fazer. Entre a assimilação e a prática, abre-se trajeto que, diante dos percalços, dos esforços sistemáticos e dos inevitáveis confrontos, pode ser abandonado antes mesmo dos primeiros passos.

Os primeiros passos - universalizar o cotidiano, abrir os olhos ao ignorado, absorver novas orientações aos velhos caminhos, aplicar teorias pedagógicas e sistemas filosóficos, provocar confrontos e conformações - são dados. Os passos seguintes cabem aos leitores. O cronista-educador já mostrou o que fazer. Portanto, os leitores precisam refletir pedagógica, literária e filosoficamente sobre como fazer, alcançando a máxima de Paulo Freire de que a 
mudança social e a transformação pedagógica iniciam-se, antes de manifestações grupais, pelo indivíduo.

\section{REFERÊNCIAS}

ANTUNES, Irandé. Lutar com palavras - coesão e coerência. São Paulo: Parábola, 2010.

CANDIDO, Antônio. Iniciação à Literatura Brasileira. Rio de Janeiro: Ouro Sobre Azul, 2007.

COUTINHO, Afrânio. Notas de teoria literária. Petrópolis: Vozes, 2008.

GALVANI, Walter. Crônica - o vôo da palavra. Porto Alegre: Mediação, 2009.

Recebido: maio de 2012 